\title{
STUDY OF CONSUMER BEHAVIOUR
} TOWARDS DIGITAL PAYMENT: AN EMPIRICAL STUDY WITH REFERENCE TO
KOLKATA

\author{
Samrat Banerjee \\ Assistant professor in commerce \\ St. Xavier's University, Kolkata, West Bengal, India
}

\author{
Prerona Saha \\ B.Com Hons. \\ St. Xavier's University, Kolkata, West Bengal, India
}

\begin{abstract}
The Digital India program is a distinguished government program undertaken by the Government of India that has an intention of making the country a digital society and a knowledge economy. The slogan and professed role of Digital India is "faceless, paperless and cashless". Different methods of electronic payments are available to promote transactions involving no cash and turn India into a cashless society. These methods include debit/credit cards, Unified Payment Interface (UPI), Aadhaar Enabled Payment System (AEPS), Unstructured Supplementary Service Data (USSD), numerous mobile payment wallets, micro-ATM etc. This study focuses on the attitude, perception of the urban consumers towards various digital payment methods. Responses from 100 respondents of Kolkata have been recorded using purposive sampling method and are analysed using anova.
\end{abstract}

Keywords- Digital Payment, ANOVA, Consumer behaviour

\section{INTRODUCTION}

India is moving on the track of the most important digital revolution. Replacing paper money with digital cash makes the greatest modification in all fields in India, which changes our economic structure notably. Currency has not fully CHANGED, AND it has its own merits and demerits. In paper currency transactions, there is a direct touch between clients and banks. But physical currency has chances of getting damaged and is difficult to carry, additionally there are possibilities of black money. Earlier, paper money transactions influence the clients and banking transactions, delay in transaction is one of the foremost problems. Entry of digital coins and e-banking centers adjusted in the lifestyle of mankind. Banks are moving from conventional ideas to fashionable concepts. Digital foreign money and e-banking gives various facilities amongst banks and clients. Anybody can get admission to their banking transactions anywhere, at any time without moving physically to bank. Only a computer application or software, and a web connection are enough. It is quite easy to access and decreases workload of banks and is very simple for balance enquiry and so on. Banks can manipulate and manage transactions within seconds, with just a few clicks. It is spread worldwide, which gives it its own demerits. One of the major demerits is the difficulty to understand and use digital money because of its complexity and the risk of viruses, hackers and havoc. Unawareness is certainly one of the biggest troubles. People are opting for on-line banking in an effort to keep away from queues, banks additionally offer help for this. Besides, those online facilities ensure safety to a great extent. When evaluating city and rural vicinity, we will reach a conclusion that humans in urban regions widely use digital foreign money and ebanking facilities as compared to people in rural areas. Reasons for that include unawareness, lack of acceptance of technology, risk of fraud, malwares, hackers. Their misconception about internet banking and the usage of digital cash, prevents them from enjoying the benefits of a cashless economic system.

In accomplishing the authorities' hard assignment of shifting India from cash based to a less coins-reliant economic system, the University Grants Commission (UGC) came ahead and issued an advisory on June 6, 2017, asking academic institutes to adopt on line payment methods. The order came after the Ministry of Human Resource Development (MHRD) called all independent establishments to join this "difficult task". Acting at the government's directions, UGC in its declaration recommended that each one receipts and payments associated with the functioning of the institutions (pupil expenses, examination expenses, vendor bills, profits/salary bills and so forth.) shall be made handiest through on-line or digital modes.

All the administrators and college students, the corporations and different commercial enterprise institutions at the campuses can be educated in the use of the BHIM app with the aid of linking their financial institution bills with the cell quantity/Aadhaar number," the letter from UGC secretary Jaspal S Sandhu said. 


\section{International Journal of Engineering Applied Sciences and Technology, 2021 \\ Vol. 6, Issue 1, ISSN No. 2455-2143, Pages 159-167 \\ Published Online May 2021 in IJEAST (http://www.ijeast.com)}

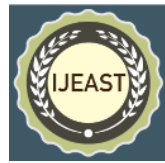

In a video conference heads of universities and other higher educational establishments were appealed to receive not anything in coins (rate/fines/deposits) and pay nothing in cash (wages/salaries/seller bills) and increase a cashless campus (covering stores/canteens/services). And to promote digital monetary transactions in establishments, the Ministry also launched the VittiyaSaksharta Abhiyan (Financial Literacy Programme) marketing campaign. On end of this campaign, 2,363 establishments suggested that they have absolutely converted to the digital payment systems.

Importantly, a number of the colleges inside the United States stated they have followed virtual payments systems for pretty a while.

In Panjab University, Chandigarh, the power for on-line charge of fees for college kids began manner back in 2010. "About 95 according to cent of all transactions being carried out by the college, which include bills of personnel or companies, are being controlled cashlessly simplest," stated Renuka Salwan, Director Public Relations (DPR), Panjab University.

"In the campus, all kinds of centers are being furnished to college students for cashless bills like credit score card, Paytm and debit cards. All 194 schools affiliated to the university use digital price methods, whilst 137 colleges have their information digitized," MsSalwan in addition delivered.

She additionally talked about that this 12 months' online admission are being controlled through cloud-based totally gadget to decorate transparency and a couple of options were supplied to the scholars for admission associated payments, making it a hassle-loose procedure.

In Chennai, Anna University followed digitization in all its receipts, payments and transactions inside the campus, lower back in 2013. "We are collecting the examination costs and training fees in on line mode simplest, we also plan to introduce a web mode to collect exam prices from affiliated college students as properly," said S. Ganesan, Registrar, and Anna University.

\section{LITERATURE REVIEW}

Malecki (2003) the creator discussed the shortcomings of digital movement in rural America. The developing usage of virtual generation is the want of the hour but most part of rural America continues to be not geared up with the identical. The important motive for this kind of backwardness is associated with shortages of human capital. Due to better profits generating possibilities, a much broader segment of the operating populace base has shifted their base from rural areas to city areas. The end result is a downward boom of economic pastime. The shortcomings may be addressed with the help of greater immigration and return migration policy. If the reasons for leaving one's personal area are addressed well, then it could be seen that lack of earnings generating possibility may be the principal reason for transferring the base. If this trouble is addressed nicely and adequate earnings producing opportunities are created, then return migration may be possible. The digital motion may additionally assist to create these varieties of job possibilities which the younger generations are looking for. The machine can also grow to be helpful for folks that are living other locations as they need a system to remittance financial resources. The influx of economic assets thru this technique will ultimately help to bring economic increase of the economy of that precise location.

Yang etal (2005) the authors advanced a case have a look at method thru this paper to look the operational performance of small network banks. Community banking is a device which serves a specific geographical area. The business possibility is confined for this kind of banking system. The participants of the banks are ordinarily the representative of that village wherein the bank is positioned. Due to sluggish operations and profitability component, they're capable of preserve due to neighborhood information and needs. But due to enlargement of commercial enterprise sports, numerous other players also are started getting into their commercial enterprise territory. This makes them considering developing better cost added and customer pleasant offerings. E - Banking is a machine which enables to create this kind of opportunities for them. As the market will become more competitive the urge to offer those styles of offerings turn out to be extra crucial.

Bamasak (2011) concluded that there has been a greater destiny for m-fee. An unlawful use of cell phones and safety of payments through cell phones were the serious problems in virtual charge machine.

Mukherjee (2011) the creator mentioned the role of Information and Communication Technology to deliver improvement inside the rural zone.

Ananthetal (2011) the paper tries to focus on the distinct elements of the utility of technology and generation in rural regions of Ethiopian economic system. Poverty is sincerely an vital difficulty however there is a wish to enhance the equal if the prevailing centers are to be carried out well. It is well known fact that the agricultural economy can't develop on its personal without the right combo of technology and technology. The Ethiopian authorities is attempting to expand that base with the assist of which the poverty remedy program may additionally able to get momentum.

Sharma (2012) the writer describes the need of net banking inside the rural areas. The Indian economy is especially ruled by way of rural humans. Approximately 6 lakhs villages are there in the country with $70 \%$ of the population are still dwelling inside the rural areas. Serving this big population base is not a clean task because of diverse nature of the agricultural 


\section{International Journal of Engineering Applied Sciences and Technology, 2021 \\ Vol. 6, Issue 1, ISSN No. 2455-2143, Pages 159-167 \\ Published Online May 2021 in IJEAST (http://www.ijeast.com)}

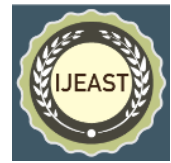

economy and its livelihood. It is crucial to provide offerings which traditional banking centers may not be able to offer with the assist of present banking device. So, there is a want to create alternative service solely for the agricultural bad. Before that it is crucial to judge the particular service requirement which the rural human beings are seeking out. Services and centers furnished at the non rural areas might not be superimposed. Thus, the author has identified 17 elements which may additionally create bottleneck for the banks to offer services to the terrible. Factors like good enough arrangement of ATMs, customer schooling facility, fee of maintaining financial institution debts, transportation and many others. Are some of the elements which may additionally create trouble? Unless and till those facilities are not stepped forward the banks won't be able to provide the services required within the rural zone.

Akinola (2012) the paper examines the safety and reliability part of cashless society. It is a truth that cashless society has many benefits and it can lead to reduce corruption, crimes on the one hand and alternatively it will able to boom the authority's revenue to a first-rate volume. Government may additionally pressure to implement the cashless system by making use of certain rules and guidelines but it can fail if the provider receivers aren't in a position to apprehend the capability blessings. Most of the time clients perceive that there may be a few amounts of security threats so one can result in loss of money. This is to a degree real as this type of undesirable event does manifest. Second aspect is related to lack of knowhow and lack of awareness approximately the utilization pattern of the offerings. It is obvious that the cashless system is required however on the identical time it ought to able to win the self belief of the service receivers.

Liu, et al (2012) discovered that digital pockets bills gave extra comfort to customers by way of presenting flexible payment options and increasing pace of transactions.

Padashetty and Kishore (2013) discovered that ease of use, expressiveness and agree with inspired adoption of digital fee via wallets and those also acted as motivators to undertake virtual price.

Roy and Sinha (2014) indicated that e-payment structures had grown substantially in India and there was a greater scope for growing usage of digital bills. They additionally observed that innovativeness, incentives, comfort and felony provisions had been contributing to improve the e-price device.

Rouibah (2015) confirmed that poor protection, lack of consider, fear of failure, excessive charges and poor familiarity have been the essential constraints that affected e-payments. Besides, safety functions of internet, banking centers, privateness and best of services were additionally affecting adoption of e-payments.
Rathore (2016) said that virtual fee the use of wallet become fantastically handy for purchasers in shopping merchandise thru on-line without physical actions throughout places

Singh (2017) concluded that there was good sized distinction among schooling of purchasers and acceptance of digital payments. The notion customers have regarding virtual fee had great impact on acceptance of virtual price amongst purchasers.

\section{OBJECTIVES OF THE STUDY}

- To understand factors of replacing paper transactions with digital transactions and its effects on customers.

- To study about the variables that impact buyers in reception of mobile wallet.

- To know about the ability of the urban consumers to access e-banking transactions and usage of digital cash when and where required.

- To study the major problems faced by people while using digital cash instead of paper currency.

- To understand the awareness of people about digital currency and its transactions.

\section{RESEARCH Methodology}

The data from which we will apply statistical methodology is primary data. Data have been collected for this research project by self-administration. A structured questionnaire was produced because it takes less time and is much more easily tabulated and interpreted from the information point of view. Respondents are more likely to respond directly. The sample size was 100 as data was collected from 100 respondents of Kolkata for the purpose. The responses are placed on Likert Scale and are analysed with the help of ANOVA.

\section{EXPERIMENT AND RESULT}

Findings from Primary Data:

- $72 \%$ of the respondents have already married and $28 \%$ of them are not yet married.

- $\quad 69 \%$ among the respondents have nuclear families and $31 \%$ of them have joint families.

- $90 \%$ of them said they use mobile payment wallet/digital payment.

- $14 \%$ of respondents said always and $27 \%$ often use digital modes of payment for making payments for purchases and bills, $21 \%$ use occasionally whereas $24 \%$ said rarely and $14 \%$ of them said never use digital modes of payment for making payments for purchases and bills.

- $43 \%$ of them said they agree and $11 \%$ said they strongly agree they use a particular app/brand/mode for all my digital payments, $20 \%$ of them responded 
neutral while $18 \%$ of them said they disagree whereas $8 \%$ responded strongly disagree.

- $40 \%$ of the subjects agree and $13 \%$ strongly agree to the statement Digital payment mode is convenient to use, $19 \%$ of them remained neutral in the context while $22 \%$ of the total respondents disagreed to this and $6 \%$ respondents strongly disagree to this statement.

- $36 \%$ of respondents have agreed while $17 \%$ of them strongly agree that Mobile Payment Wallet/Digital Payment Transactions are safe and secure, $20 \%$ of them were neutral in this matter but $18 \%$ respondents have disagreed while $9 \%$ of them respondents strongly disagree.

- $36 \%$ of respondents have agreed while $17 \%$ of them strongly agree that Mobile Payment Wallet/Digital Payment Transactions save a lot of time, $18 \%$ of them were neutral in this matter but $21 \%$ respondents have disagreed while $8 \%$ of them respondents strongly disagree.

- $40 \%$ of the total respondents agree and $15 \%$ strongly agree electronic wallets can provide benefits to individuals while purchasing various products., $19 \%$ of them said they were neutral although 19\% of the respondents have disagreed while $7 \%$ respondents strongly disagreed.

- $\quad 39 \%$ among all respondents agree and $18 \%$ strongly agree that using mobile wallets improve the quality of my decision-making while buying different products, $17 \%$ of them decided to stay neutral while $20 \%$ of them disagree and $6 \%$ respondents have strongly disagreed.

- $\quad 37 \%$ of the subjects agree and $21 \%$ strongly agreed when asked if they believe mobile wallets are more beneficial compared to the traditional methods, $20 \%$ of them chose to stay neutral but $17 \%$ of them disagree to this while $5 \%$ of the people strongly disagreed.

- $\quad 34 \%$ of the respondents have agreed and $26 \%$ strongly agreed that Mobile wallets provide them with a wider variety of payment options and other financial services, $18 \%$ of the respondent chose to remain neutral while $19 \%$ of them disagree but $3 \%$ strongly disagreed.

- $\quad 36 \%$ of the respondents have agreed and $18 \%$ strongly agree that interacting with mobile wallet is helpful, $21 \%$ of them chose to remain neutral while $15 \%$ of respondents have disagreed and $10 \%$ of them strongly disagreed.

- $38 \%$ of the respondents said they agree and $19 \%$ strongly agree they have faith in the service providers of electronic wallet apps, $16 \%$ of them said they were neutral and $20 \%$ of them disagree and $7 \%$ of respondent strongly disagree.

\section{HYPOTHESES STATEMENT}

1.There is a significant difference between gender of the respondents and perception towards use of Digital Payments. (Alternate Hypothesis $\mathrm{H}_{1}$ )

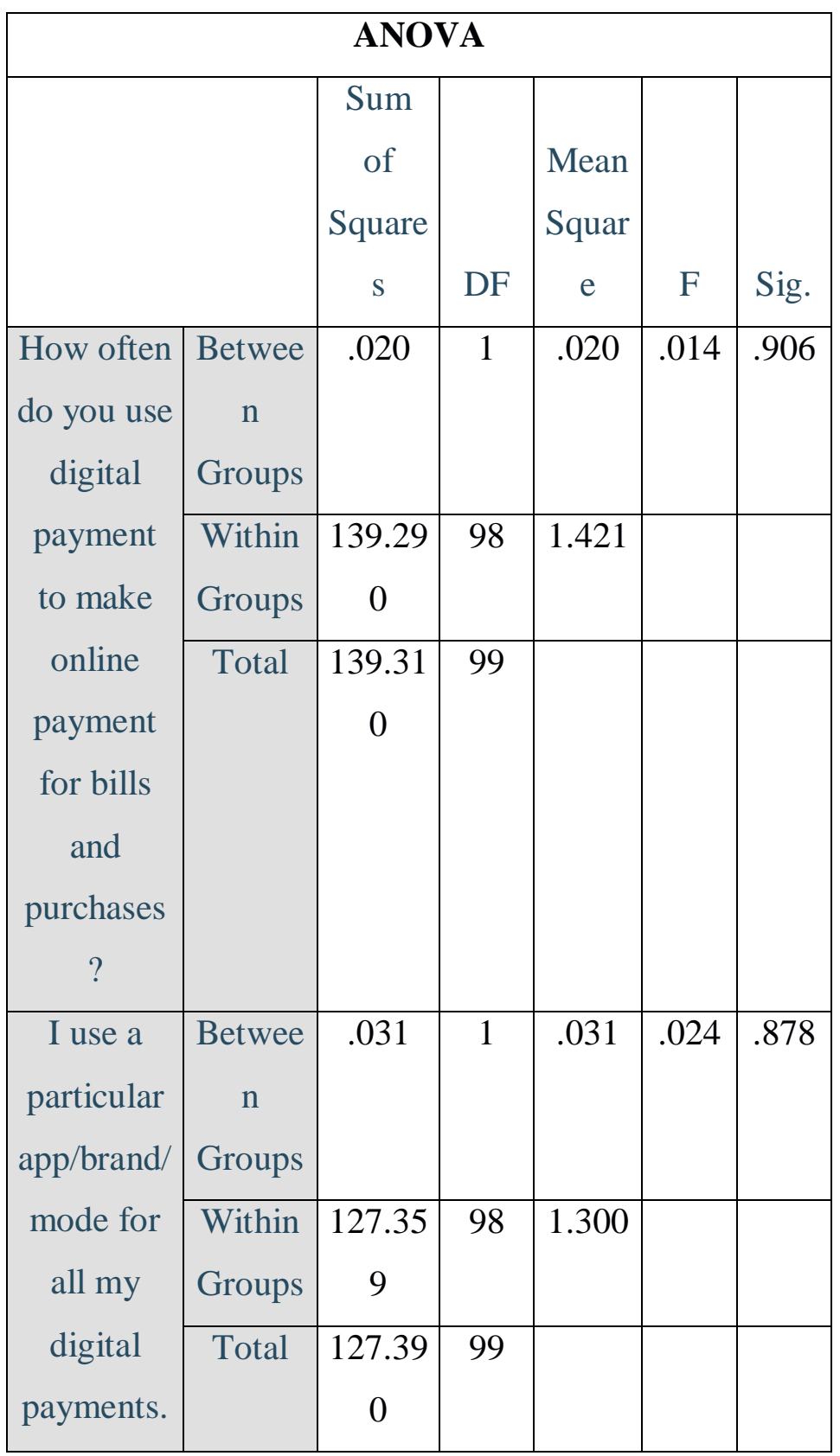


International Journal of Engineering Applied Sciences and Technology, 2021

Vol. 6, Issue 1, ISSN No. 2455-2143, Pages 159-167

Published Online May 2021 in IJEAST (http://www.ijeast.com)

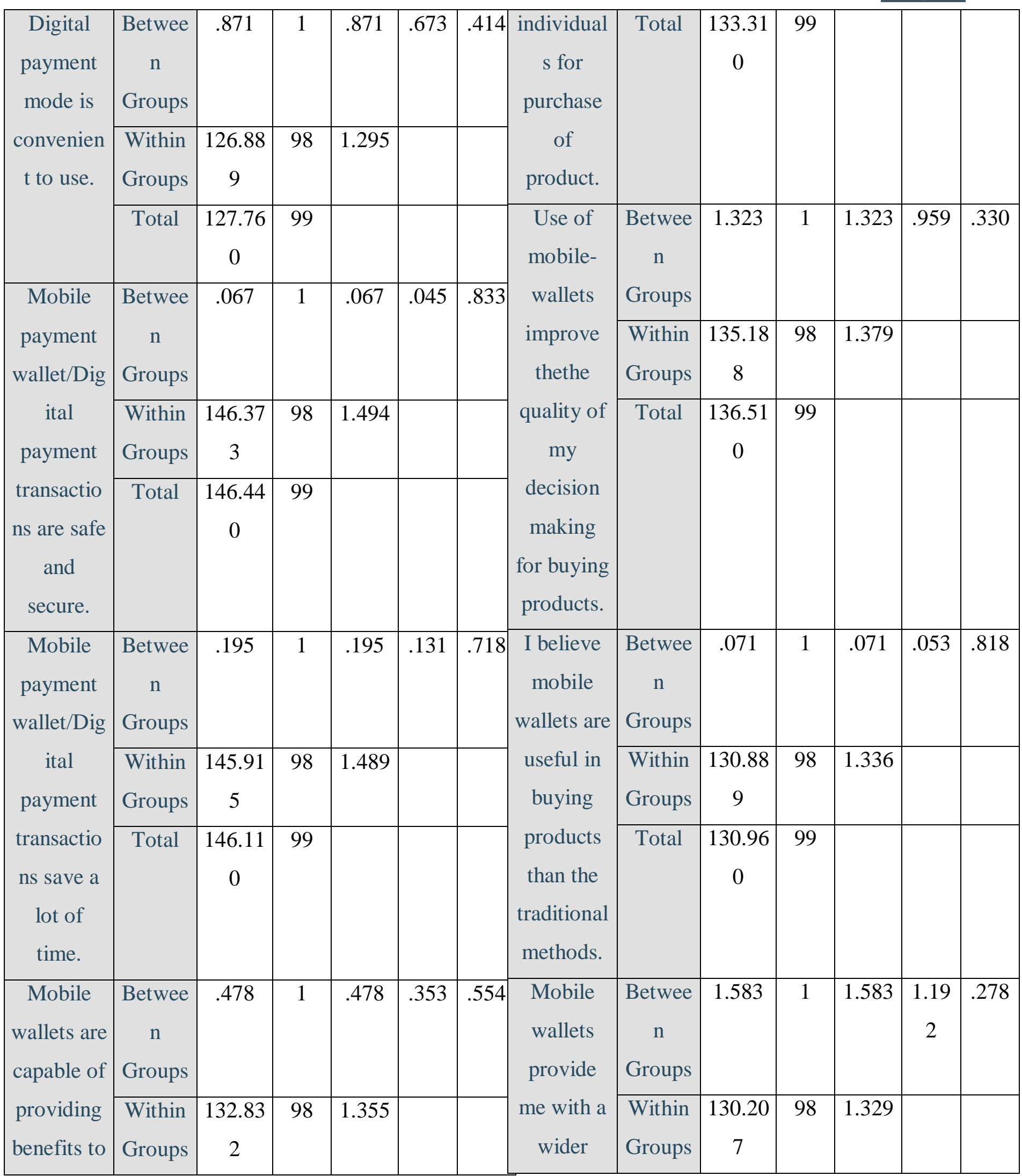


Published Online May 2021 in IJEAST (http://www.ijeast.com)

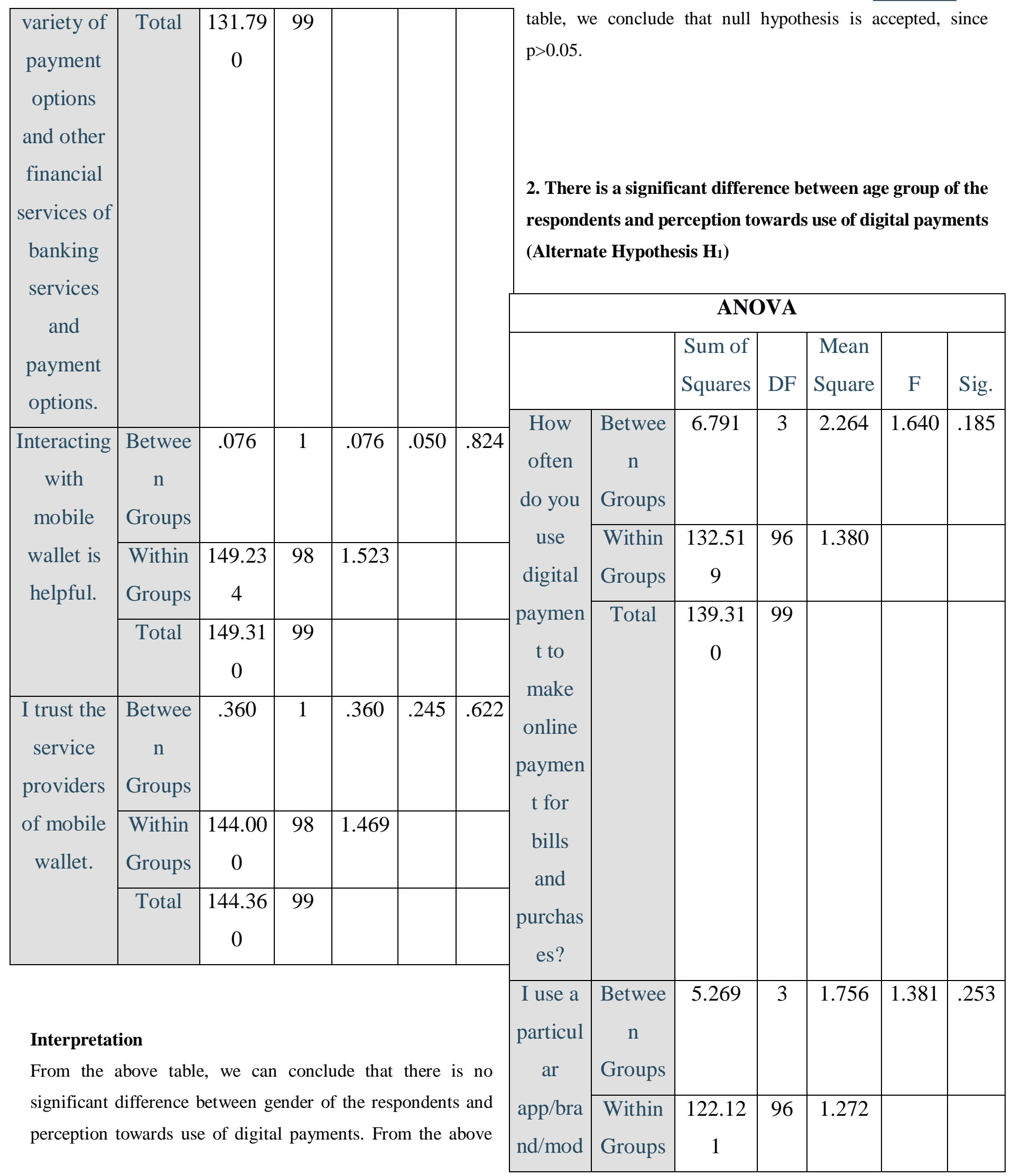


International Journal of Engineering Applied Sciences and Technology, 2021

Vol. 6, Issue 1, ISSN No. 2455-2143, Pages 159-167

Published Online May 2021 in IJEAST (http://www.ijeast.com)

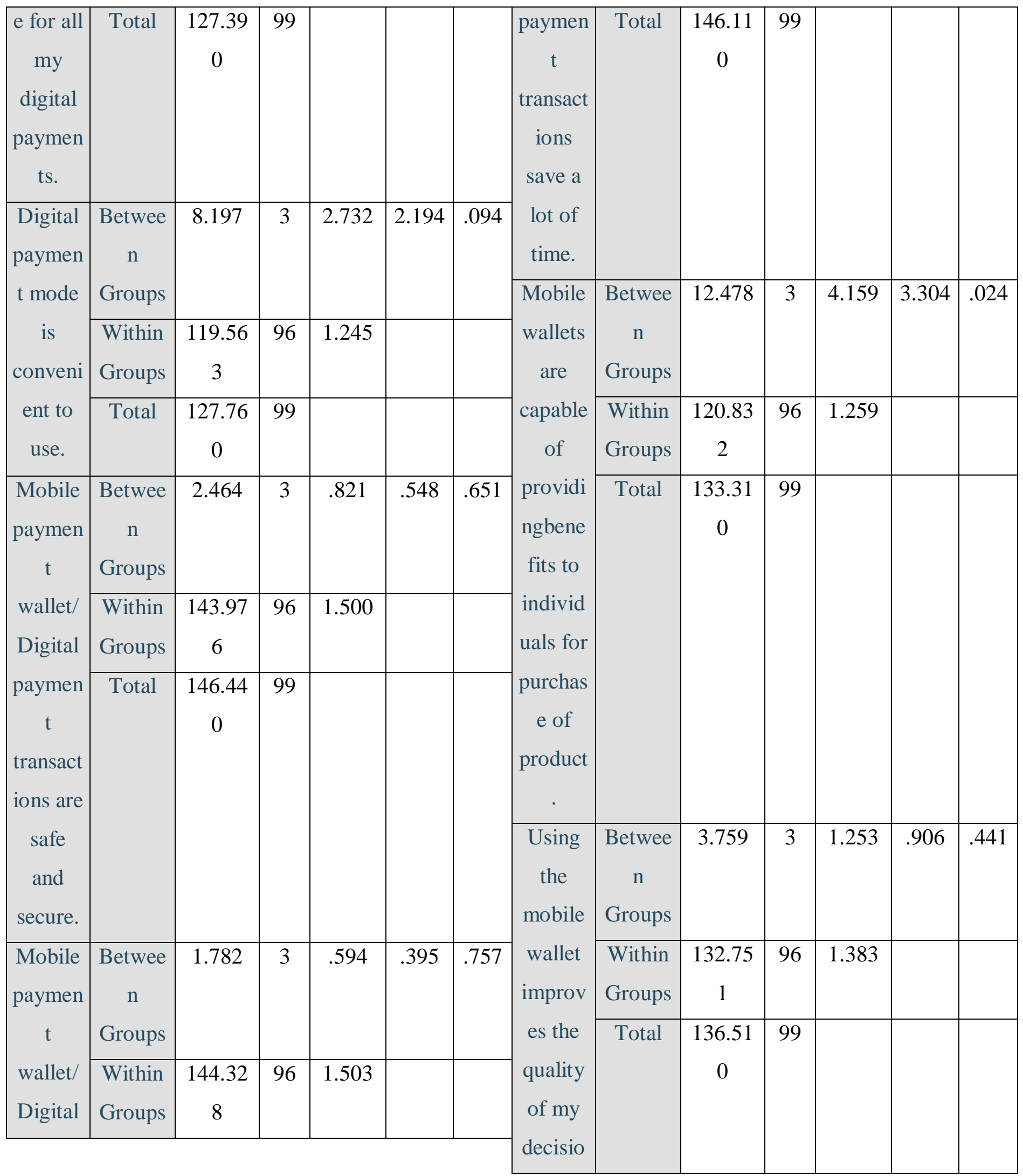




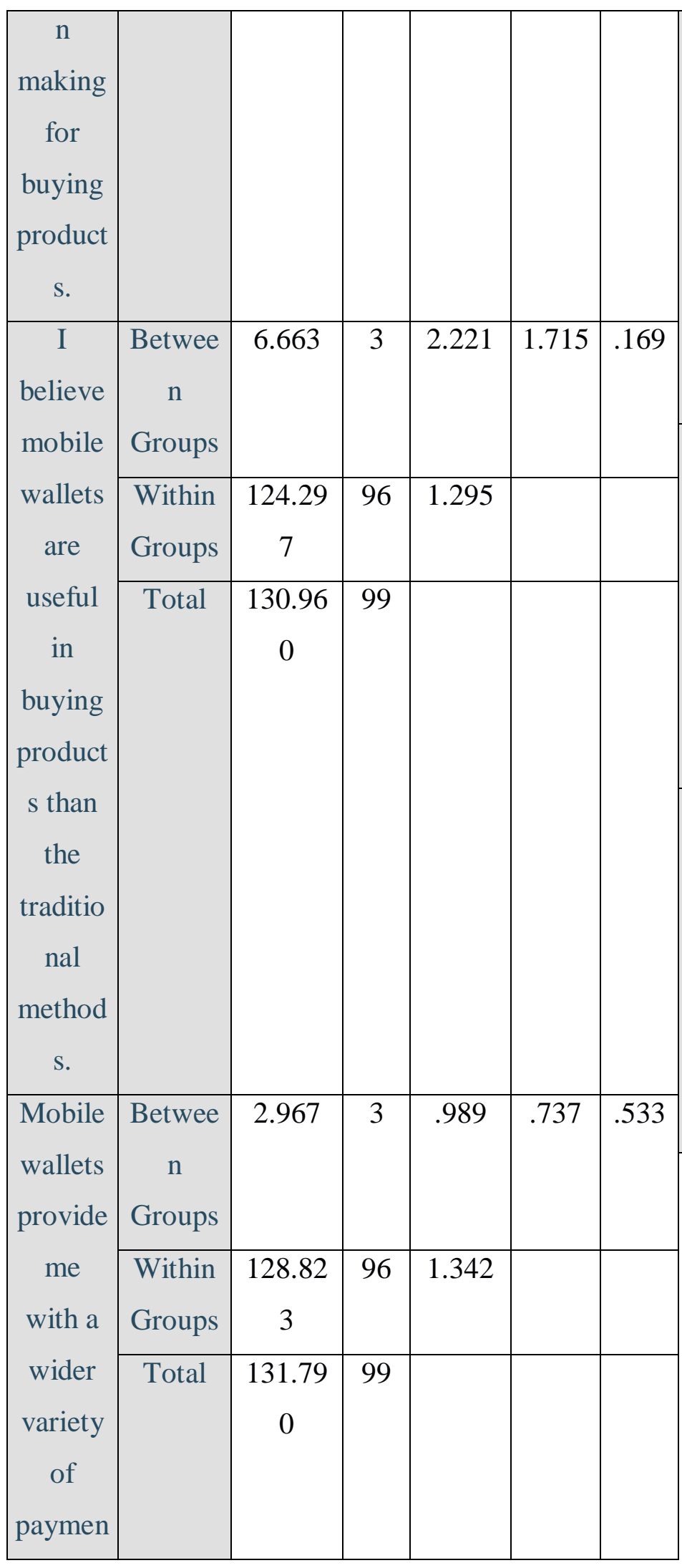

\begin{tabular}{|c|c|c|c|c|c|c|}
\hline $\begin{array}{c}\mathrm{t} \\
\text { options } \\
\text { and } \\
\text { other } \\
\text { financi } \\
\text { al } \\
\text { service } \\
\text { s. }\end{array}$ & & & & & & \\
\hline $\begin{array}{c}\text { Interact } \\
\text { ing } \\
\text { with }\end{array}$ & $\begin{array}{c}\text { Betwee } \\
n \\
\text { Groups }\end{array}$ & 3.119 & 3 & 1.040 & .683 & .565 \\
\hline $\begin{array}{l}\text { mobile } \\
\text { wallet }\end{array}$ & $\begin{array}{l}\text { Within } \\
\text { Groups }\end{array}$ & $\begin{array}{c}146.19 \\
1\end{array}$ & 96 & 1.523 & & \\
\hline $\begin{array}{c}\text { is } \\
\text { helpful. }\end{array}$ & Total & $\begin{array}{c}149.31 \\
0\end{array}$ & 99 & & & \\
\hline $\begin{array}{l}\text { I trust } \\
\text { the } \\
\text { service }\end{array}$ & $\begin{array}{c}\text { Betwee } \\
\text { n } \\
\text { Groups }\end{array}$ & .818 & 3 & .273 & .182 & .908 \\
\hline $\begin{array}{c}\text { provide } \\
\text { rs of }\end{array}$ & $\begin{array}{l}\text { Within } \\
\text { Groups }\end{array}$ & $\begin{array}{c}143.54 \\
2\end{array}$ & 96 & 1.495 & & \\
\hline $\begin{array}{l}\text { mobile } \\
\text { wallet. }\end{array}$ & Total & $\begin{array}{c}144.36 \\
0\end{array}$ & 99 & & & \\
\hline
\end{tabular}

\section{Interpretation}

Thus, there is no significant difference between age group of the respondents and perception towards use of digital payments. So, the null hypothesis is accepted ( $p>0.05)$.

\section{CONCLUSION}

With a click of a button, smart phones and internet services simplified life. In the end, this increases consumer needs and expectations. Cashless payments have almost replaced physical cash transactions, as it is being used more widely. Depending on how it is being used by the common people and financial 


\section{International Journal of Engineering Applied Sciences and Technology, 2021 \\ Vol. 6, Issue 1, ISSN No. 2455-2143, Pages 159-167 \\ Published Online May 2021 in IJEAST (http://www.ijeast.com)}

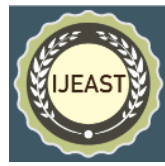

institutions like banks and the handling of data, there are still some limitations in terms of privacy and safety. The objective of the study was therefore to analyze the views of consumers regarding digital transactions plus, the protection of information in a cashless economy. Findings from the study show tha.t most consumers prefer credit or debit cards, and that mobile wallets follow the most comfortable method of payment. The most important factors influencing consumers in cashless transactions have also been found to be privacy and security, followed by convenience. Digishala is also a guide to the use of digital payments by consumers. The study also showed that users understand the security of information in non-cash transactions.

Suggestions:

- Try downloading apps for payment from authentic sites like Google Play and the Apple Store online.

- Always verify the producer of the app you want to download. The 'Top Developer' badge (in Google Play) is usually a good sign that the app is safe. Go through the reviews too.

- Check the approvals required by the app. If it is requesting more permissions then it should in your opinion, better avoid installing it.

- Never open a website for banking or shopping with links sent through e-mail or texts.

- To make payments, you must choose established and popular websites.

- Make sure the online transactions are verified by two factors. That means that you have to authenticate twice each time you make a payment. For example, provide your login ID\& password as well as a One Time Password, when paying via a net banking system. Thus, even if a hacker cracks your password or other details, a fraudulent transaction cannot be executed.

- Simply select a strong password for your online payment application accounts. Make sure that the password is at least 8 characters long, with letters, numbers and symbols in the upper case and the lower case. For instance, 'Cool15is@ King'

- Avoid cashless public computer transactions such as cyber cafés.

- Do not make online payments through free, insecure Wi-Fi networks. You can let your information be stolen by an attacker.

\section{REFERENCES}

[1] Seppa M., Liljander V., and Gummerus J., (2011), "Private bloggers' motivations to produce content: a gratifications theory perspective", Journal of Marketing Management, Vol. 27 Nos 13/14, (pp. 1479-1503).

[2] Williams B. C., and Plouffe C. R., (2007), Assessing the evolution of sales knowledge: A 20-year content analysis. Industrial Marketing Management, 36, (Pg408-419).
[3] Hameed M. A., Waqas A., Aslam M. N., Bilal M., and Umair M., (2014), Impact of TV advertisement on children buying behavior. International Journal of Humanities and Social Science, 4, (Pg246-261).

[4] Buboltz W. C., Jr. Miller M., and Williams D. J., (1999), Content analysis of research in the Journal of Counseling Psychology (1973-1998). Journal of Counseling Psychology, 46, (Pg496-503).

[5] Bamasak O., (2011), Exploring buyers acknowledgment of portable installments an observational Study. Worldwide Journal of Information Technology, Interchanges and Convergence 1, (Pg173-185).

[6] Wang X., Yu C., and Wei Y., (2012), "Social media peer communication and impacts on purchase intentions: a consumer socialization framework", Journal of Interactive Marketing, Vol. 2 No. 4, (pp. 198-208).

[7] Dahlberg T., Mallat N., Ondrus J., and Zmijewska A., (2008), Past, present and future of versatile installments inquire about: A writing survey. Electronic Commerce Research and Applications 7, (Pg165-181).

[8] Wolfinbarger M., and Gilly M.C., (2003), "eTailQ: dimensionalizing, measuring and predictingetail quality", Journal of Retailing, Vol. 79 No. 3, (pp.183-198).

[9] Van Noort G., Antheunis M., and van Reijmersdal E., (2012), "Social connections and thepersuasiveness of viral campaigns in social network sites: persuasive intent as theunderlying mechanism", Journal of Marketing Communications, Vol. 18 No. 1, (pp.39-53).

[10] Padashetty S., and Kishore KS., (2013), An Empirical Study on Consumer Adoption of Mobile Payments in Bangalore City-A Case Study. Analysts World 4, (Pg83).

[11] Taheam K., Sharma R., and Goswami S., (2016), Drivers of Digital Wallet Usage: Suggestions for Leveraging Digital Marketing. Worldwide Journal of Financial Research 13, (Pg175-186).

[12] Shin H., and Ziderman A., (2009), Student Loans Repayment and Recovery: Worldwide Comparisons. Advanced education 57, (Pg315-333).

[13] Bianchi C., and Andrews L., (2012), "Risk, trust, and consumer online purchasing behaviour: a Chilean perspective", International Marketing Review, Vol. 29 No. 3, (pp.253-275). 